year was almost double last year's, with some counts in good areas for this species.

For weather, coverage and participants, please refer to Christmas Bird Counts elsewhere in this issue. Mouse tracks, even though identified to species, have been recorded under Mouse.
Symbols found in the table are as follows:

* Identified by tracks, with the number of animals by tracks in parenthesis.

+ Seen during count period but not on count day.

D Freshly dead animal seen.

\title{
HITCH-HIKING MARMOTS
}

By KEITH SHAW, Cardston, Alta.

In June, 1969, I was driving with Don Shaw of Cardston, Alberta, on Going-To-The-Sun Highway in Glacier National Park, Montana. We had stopped just above the Weeping Wall to look at a large Whistling Marmot (Marmota caligata) by the road edge. We were distracted for a moment while getting out camera gear and when we looked for the marmot it was gone. Concluding that it had gone into a burrow since the weather was chilly, we left the area and continued without stops across Logan Pass and down the east side to Rising Sun Campground where we began to prepare lunch. A piercing whistle from beneath the car sent us to check the engine compartment for mechanical failure. Under the hood near the engine was the large marmot from the Weeping Wall, apparently unhurt but also unwilling to leave. We tried to dislodge it but then decided it would be best to finish our lunch and drive the hitch-hiker back across Logan Pass to where we had picked it up. Several whistles later and just as we were about to leave, the marmot voluntarily dropped to the ground and was last seen under a California-licensed minibus. This marmot had ridden 15 miles under our car.
Several days later I learned of a Cardston farmer who had made the same Weeping Wall stop in 1968 and had then driven directly home with only a brief stop at the Carway Customs. Shortly after arrival in Cardston a Whistling Marmot was noticed on the ground under the car. It was chased out and went directly under the farmer's truck where it disappeared in the engine compartment. Later that day the truck was driven north on the Blood Indian Reserve and parked. Shortly thereafter the marmot left the truck and ran into a grain field. This animal had travelled under two vehicles a total of 60 miles.

District Ranger Robert Frauson of Glacier National Park, Montana, reported the following incident. ${ }^{3} \mathrm{~A}$ government truck stopped in front of an apartment in the St. Mary Ranger Station housing area where a very hot and panting Whistling Marmot fell out from the engine compartment. Karen Frauson put the marmot in a box and took it into the shady woods to allow the animal to cool. She checked about a half hour later but the marmot was dead. It did not seem to be hurt and apparently died of the heat. Late June was very warm and engine heat would add to the marmot's thermal overload. 
The truck had been in Whistling Marmot habitat at Logan Pass earlier in the day.

On a cool June morning in 1973 Cardston High School teacher William Richards drove his half-ton truck to a nearby field to load old fence posts. A Yellow-bellied Marmot (Marmota flaviventris) left the post pile and climbed up near the warm engine and refused to leave. Mr. Richards drove home, unloaded the posts and drove to the Cardston High School. The truck was put in the school shop and with the aid of students the animal was dislodged and held captive for the day. In the afternoon $\mathrm{Mr}$. Richards took the marmot back to its field and turned it loose. This marmot had travelled 7 miles under the truck.

Occasional sightings of marmots in unlikely places have been reported. In September, 1975, a neighbor drew my attention to a Yellow-bellied Marmot in a culvert near the Chinook Senior Citizens' Home in Cardston. The nearest known colony is 4 miles on up Lee Creek near a ranch road. Perhaps it had hitch-hiked to town.

Banfield's report of a single specimen of Yellow-bellied Marmot taken from a rockslide in Waterton Lakes National Park where no recent signs of the species exist could well be that of a single hitch-hiking pioneer from a colony in northern Montana or southern Alberta. ${ }^{1}$

Soper reported an extraordinary record of a large male Yellow-bellied Marmot collected on the semiarid plains near Lake Newell, Alberta, on May 10, 1957.4 This animal may also have been a hitch-hiker from some distant colony.

Glacier National Park Seasonal Naturalist Marc Boyd notes that Whistling Marmots will often come close to a quietly seated hiker for no other apparent reason than heatseeking."

Colonization of new areas by hitchhiking marmots is unlikely but possible. Simultaneous hitch-hiking by a pair has not been observed. However, should a pregnant female survive a vehicle ride and disembark at a location favorable to survival, then the probability of colonizing a new site is enhanced.

Roadside Whistling Marmots are of great interest to tourists in Glacier National Park and marmot loss from within the park due to hitch-hiking is a problem worthy of consideration. In fact, hitch-hiking may account for the unexplained disappearance of roadside marmots on Going-To-The-Sun Highway. Roads in Waterton Lakes National Park do not cross typical marmot habitat and, therefore, populations of Whistling Marmots are not apt to decline because of hitchhiking.

'BANFIELD, A. W. F. 1974. The mammals of Canada. Univ. of Toronto Press, Toronto. 438 p. "2BOYD, MARC. 1975. Personal communication to the author.

'FRAUSON, ROBERT. 1975. Personal communication to the author

${ }^{4}$ SOPER, J. D. 1964. The mammals of Alberta. Queen's Printer, Edmonton. 410 p.

\section{CHURCHILL RIVER ISSUE}

Issue No. 15 of The Musk-Ox (February, 1975) is devoted to several aspects of the Churchill River. The seven articles listed below fill the first 64 pages, while the remaining 14 pages deal with other aspects of the North.

The proposed Wintego hydroelectric project on the Churchill River, Saskatchewan - SASKATCHEWAN POWER CORPORATION

The Churchill-Reindeer rivers area: evolution of the landscape - WALTER KUPSCH

A brief history of the Churchill River - W. A. DAVIES

Areas of initiation in the political geography of aboriginal minorities STEWART RABY 